\title{
Effect of Methylene Blue on Pyridine Nucleotides and Insulin Secretion of Rat Pancreatic Islets
}

\author{
H. P. T. Ammon and E. J. Verspohl \\ Abteilung für Pharmakologie der Universität Erlangen-Nürnberg, and Pharmazeutisches Institut der Universität Tübingen, FRG
}

Summary. Methylene Blue, which is known to oxidise NADPH in red blood cells, was used to assess a possible role of NADPH in the glucose-stimulated secretion of insulin. When islets from rats were incubated with $3 \mathrm{mg} / \mathrm{ml}$ of glucose, Methylene Blue $(0.5$, $1.0,2.0$ or $5.0 \mathrm{\mu g} / \mathrm{ml}$ ) significantly decreased the concentration of NADPH, increased that of $\mathrm{NADP}^{+}$and decreased the NADPH/NADP ${ }^{+}$ratio in a dosedependent manner. This effect was associated with inhibition of the glucose-induced insulin release. No significant change of $\mathrm{NADH}, \mathrm{NAD}^{+}$and $\mathrm{ATP}$ could be observed. It is suggested that the secretory response of the pancreatic islet to glucose stimulation depends on the NADPH/NADP ${ }^{+}$ratio.

Key words: Rat islets of Langerhans, glucose, Methylene Blue, NADPH/NADP ${ }^{+}, \mathrm{NADH} / \mathrm{NAD}^{+}$, insulin secretion, ATP.

Insulin release in response to pentoses and pentose derivatives has been reported [1]. Decreased activity of the pentose phosphate shunt and/or decreased $\mathrm{NADPH} / \mathrm{NADP}^{+}$ratios in pancreatic islets, has been observed in fetal rats [2] during old age [3], after in vitro addition of exogenous insulin [4], during starvation (Ammon \& Wagner-Teschner, unpublished work), in islets of rats previously treated with 6aminonicotinamide [5] or after in vitro addition of chlorpromazine [6] and associated with a decreased secretory response to glucose. These observations draw attention to the possibility that the pentose phosphate shunt and the $\mathrm{NADPH} / \mathrm{NADP}^{+}$ratio might be involved in the mechanism of glucoseinduced insulin release [1-8]. We have attempted to elucidate a possible role of islet NADPH in insulin secretion by using Methylene Blue which is known to oxidise NADPH in red blood cells [9].

\section{Materials and Methods}

Animals. Male and female Wistar rats from a local strain weighing 200 to $300 \mathrm{~g}$ were used. They were kept on a standard pellet diet (Herilan ${ }^{2}$, Eggersmann Corp., Rintelen/Weser, West Germany) and tap water ad libitum.

Chemicals. Collagenase of highest purity (CLS grade) from Worthington Biochemical Corp., New Jersey, USA and from Serva, Heidelberg, West Germany, was used. Bovine serum albumin was obtained from Behringwerke AG, Marburg, West Germany, and ATP from Boehringer, Mannheim, West Germany. Methylene Blue was from Fluka Feinchemikalien, $\mathrm{GmbH}$, NeuUlm, West Germany. Other chemicals of analytical grade were obtained from E.Merck, Darmstadt, West Germany. Insulin Radioimmunoassay Kits were supplied by Isotopendienst West, West Germany. Rat insulin was a gift of Novo, Copenhagen, Denmark.

Incubation of Islets. The rats were anaesthetised with ether, and the pancreatic islets were harvested by the collagenase method decribed by Lacy and Kostianovsky [10]. For the incubation studies we used bicarbonate buffered medium [11] supplemented with $2 \mathrm{mg} / \mathrm{ml}$ albumin, and gassed for $10 \mathrm{~min}$ with carbogen (95\% $\mathrm{O}_{2}: 5 \% \mathrm{CO}_{2}$ ). Islets were first incubated for $30 \mathrm{~min}$ in this medium containing in addition $0.3 \mathrm{mg} / \mathrm{ml}$ of glucose while being gassed with carbogen. Batches of 10 islets were then incubated in $0.7 \mathrm{ml}$ of medium in the presence of 0 or $3 \mathrm{mg} / \mathrm{ml}$ of glucose with or without $0,0.5,2.0,5.0 \mathrm{ug} / \mathrm{ml}$ of Metylene Blue at $37^{\circ} \mathrm{C}$ for $60 \mathrm{~min}$. Further details are given in the legends of the figures and tables.

Pyridine Nucleotides. The contents of total islet $\mathrm{NAD}(\mathrm{P}) \mathrm{H}$ and $\mathrm{NAD}(\mathrm{P})^{+}$were assayed by a fluorimetric technique according to the principles described by Passoneau and Lowry [12]. At the end of incubation period, the glass tubes were placed in an ice bath and medium around the islets was immediately removed by sucking. For the determination of NADPH and NADH islets were then 

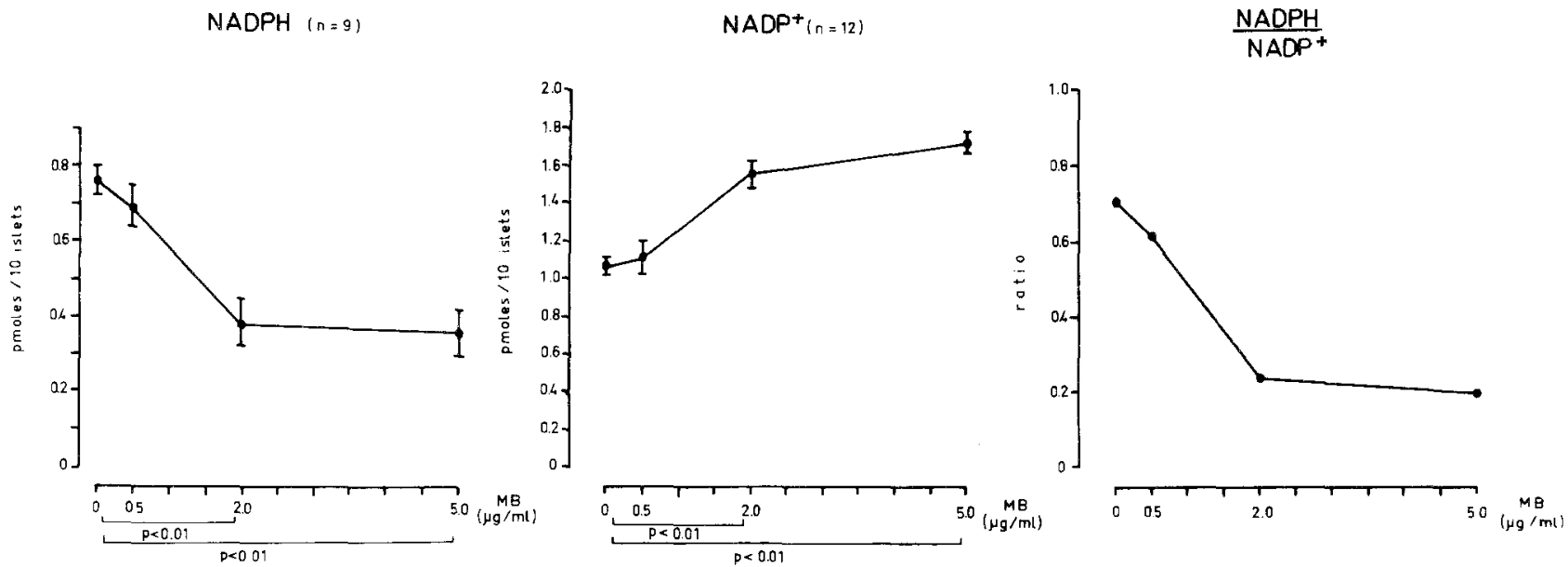

Fig. 1. Effect of Methylene Blue (MB) on the concentrations of NADPH and NADP ${ }^{+}$, and on the NADPH/NADP ${ }^{+}$ratio in isolated pancreatic rat islets. Ten islets were incubated in $0.7 \mathrm{ml}$ of medium containing $3 \mathrm{mg} / \mathrm{ml}$ of glucose with or without Methylene Blue over a period of 60 min. Mean \pm SEM; $n=$ number of experiments

Table 1. $\mathrm{NAD}^{+}, \mathrm{NADH}, \mathrm{NAD}^{+}+\mathrm{NADH}, \mathrm{NADH} / \mathrm{NAD}^{+}$ratio and $\mathrm{ATP}$ in rat islets exposed to Methylene Blue. Ten islets were incubated in $0.7 \mathrm{ml}$ of medium containing $3 \mathrm{mg} / \mathrm{ml}$ of glucose with or without Methylene Blue over a period of $60 \mathrm{~min}$. The sum of NADH and $\mathrm{NAD}^{+}$does not yield values of 4 th column $\left(\mathrm{NAD}^{+}+\mathrm{NADH}\right)$ because the latter were obtained by separate experiments. Mean values \pm SEM; all values in a column were not statistically different from each other

\begin{tabular}{llllll}
\hline \multicolumn{2}{l}{ Mmoles/10 islets } & & & \\
\cline { 2 - 5 } $\begin{array}{l}\text { Methylene Blue } \\
(\mu / \mathrm{ml})\end{array}$ & $\begin{array}{l}\mathrm{NADH} \\
\mathrm{n}=7\end{array}$ & $\begin{array}{l}\mathrm{NAD}^{+} \\
\mathrm{n}=7\end{array}$ & $\begin{array}{l}\mathrm{NAD}^{+}+\mathrm{NADH} \\
\mathrm{n}=7\end{array}$ & $\begin{array}{l}\text { NADH/NAD } \\
\mathrm{n}=7\end{array}$ & $\begin{array}{l}\mathrm{ATP}^{+} \\
\mathrm{n}=12\end{array}$ \\
\hline 0 & $5.16 \pm 0.52$ & $8.82 \pm 0.34$ & $15.12 \pm 1.06$ & 0.58 & $90.2 \pm 6.5$ \\
0.5 & $4.55 \pm 0.37$ & $8.90 \pm 0.25$ & $15.81 \pm 0.82$ & 0.51 & $74.7 \pm 3.7$ \\
2.0 & $5.62 \pm 0.45$ & $8.90 \pm 0.45$ & $16.28 \pm 1.18$ & 0.63 & $85.2 \pm 7.0$ \\
5.0 & $4.19 \pm 0.45$ & $8.98 \pm 0.79$ & $13.02 \pm 1.40$ & 0.47 & $88.2 \pm 6.0$ \\
\hline
\end{tabular}

immediately disintegrated in $20 \mu \mathrm{l}$ of a mixture of $0.5 \mathrm{mmol} / \mathrm{l} \mathrm{cys-}$ tein and $40 \mathrm{mmol} / 1 \mathrm{NaOH}$ and heated for $15 \mathrm{~min}$ at $60^{\circ} \mathrm{C}$. When $\mathrm{NADP}^{+}$or NAD ${ }^{+}$were to be determined, only $5 \mu$ l of this mixture were used and $50 \mu \mathrm{l}$ of a mixture of $\mathrm{H}_{2} \mathrm{SO}_{2}(20 \mathrm{mmol} / 1)$ and $\mathrm{Na}_{2} \mathrm{SO}_{4}(0.1 \mathrm{~mol} / \mathrm{l})$ were added and heated for $30 \mathrm{~min}$ at $60^{\circ} \mathrm{C}$. When NADH and $\mathrm{NAD}^{+}$are determined from one glass tube, the procedure for $\mathrm{NADH}$ was adopted with the exception that $\mathrm{NAD}^{+}$ was not destroyed by heating at $60^{\circ} \mathrm{C}$. The pyridine nucleotides were determined from calibration curves prepared from authentic $\mathrm{NADPH}, \mathrm{NADP}^{+}, \mathrm{NADH}$ and $\mathrm{NAD}^{+}$and taken through the same procedures. Disintegration of islets was assessed by microscopy. Recovery of NADPH added in various amounts to disintegrated islets was $98.1 \pm 3.2 \%$ (mean $\pm \mathrm{SEM} ; \mathrm{n}=8$ ).

$A T P$. In a separate series of experiments, after incubation, the islets were prepared and disintegrated as described above (see Pyridine nucleotides). Islet content of ATP was assayed according to the principles given by Matschinsky [13]. After addition of glucose and NADP ${ }^{+}$these were transformed to 6-phosphogluconate and NADPH by hexokinase and glucose-6-phosphate dehydrogenase. The NADPH produced stoichiometrically was measured by enzymatic cycling as indicated above [12].

Insulin. Insulin released into the medium was assayed by radioimmunoassay using rat insulin as a standard.
Standard Curves. To establish the non-interference of Methylene Blue with the assay of pyridine nucleotides, ATP and insulin, standard curves of these substances were examined with concentrations of Methylene Blue employed in the incubation experiments.

Statistics. The two-tailed Student's t-test was used for statistical evaluation of the results. Values were normally distributed [14] $\mathrm{P}$-value $<0.05$ was used for rejecting the null hypothesis.

\section{Results}

As shown in Figure 1, in the presence of $3 \mathrm{mg} / \mathrm{ml}$ of glucose, the addition of $0.5,2.0$ or $5.0 \mu \mathrm{g} / \mathrm{ml}$ of Methylene Blue decreased islet NADPH and increased $\mathrm{NADP}^{+}$leading to a decrease of the NADPH/NADP ${ }^{+}$ratio which was dose-dependent; the effects being statistically significant at 2.0 and $5.0 \mu \mathrm{g} / \mathrm{ml}$ of Methylene Blue. Over the same dose range, Methylene Blue did not significantly affect islet $\mathrm{NADH}, \mathrm{NAD}^{+}$, total $\mathrm{NADH}+\mathrm{NAD}^{+}$content, the NADH/NAD ${ }^{+}$ratio, or ATP (Table 1). 
Figure 2 shows that Methylene Blue significantly inhibited glucose-induced insulin release. In the absence of glucose, $5 \mu \mathrm{g} / \mathrm{ml}$ Methylene Blue, but not 1 and $2 \mu \mathrm{g} / \mathrm{ml}$, was inhibitory.

\section{Discussion}

In red blood cells NADPH is more sensitive to oxidation by Methylene Blue than is NADH [9]. As shown here with islets, $2.0-5.0 \mathrm{\mu g} / \mathrm{ml}$ of Methylene Blue decreased the NADPH/NADP ${ }^{+}$ratio whereas the $\mathrm{NADH} / \mathrm{NAD}^{+}$ratio and ATP concentration (Table 1) remained unaffected. This suggests that oxidation of pyridine nucleotides by Methylene Blue in the concentrations used in this study is limited to NADPH and that there is no disturbance of energy availability of the pancreatic islets. Similar concentrations of Methylene Blue did not affect the oxidation of $\left[6-{ }^{14} \mathrm{C}\right]$ glucose [6]. In the perfused rat pancreas inhibition of insulin secretion by identical concentrations of Methylene Blue was found to be reversible after its removal from the perfusion medium [15]. It also appears that the concentrations of Methylene Blue used in the present study did not affect the viability of pancreatic islets.

Confirming earlier observations $[6,7,15]$, Methylene Blue also diminished the secretory response of the pancreatic islet to glucose in a dosedependent manner. With allowance for the random errors, these seems to be a correlation between the effect on the NADPH/NADP ${ }^{+}$ratio and the inhibition of glucose-induced insulin release. It may, however, be noted that in our experiments, the correlation was not absolute. This may in part be due to the fact that not only Methylene Blue but also insulin released into the medium (the highest concentration appears at the end of the incubation period) possess a lowering effect on islet NADPH/NADP ${ }^{+}$[4]. Thus the actual NADPH/NADP ${ }^{+}$ratio determined at the end of the incubation period represents the effect of insulin alone when Methylene Blue is absent) or the combined effect of Methylene Blue plus secreted insulin. Nevertheless our data suggest that the ability of glucose to stimulate the secretion of insulin somehow depends on the NADPH/NADP ${ }^{+}$ratio (i.e. glucose is more effective in stimulating insulin release when the NADPH/NADP ${ }^{+}$ratio is high). It remains to be determined whether the mitochondrial action of glucose on insulin secretion depends on the cytosolic or NADPH/NADP ${ }^{+}$ratio or perhaps both.

The flux through the pentose phosphate shunt [16] and the NADPH/NADP ${ }^{+}$ratio [17] of pancreatic islets increase when the glucose concentration is raised from 5.6 or $16.7 \mathrm{mmol} / \mathrm{l}$. It is therefore con-

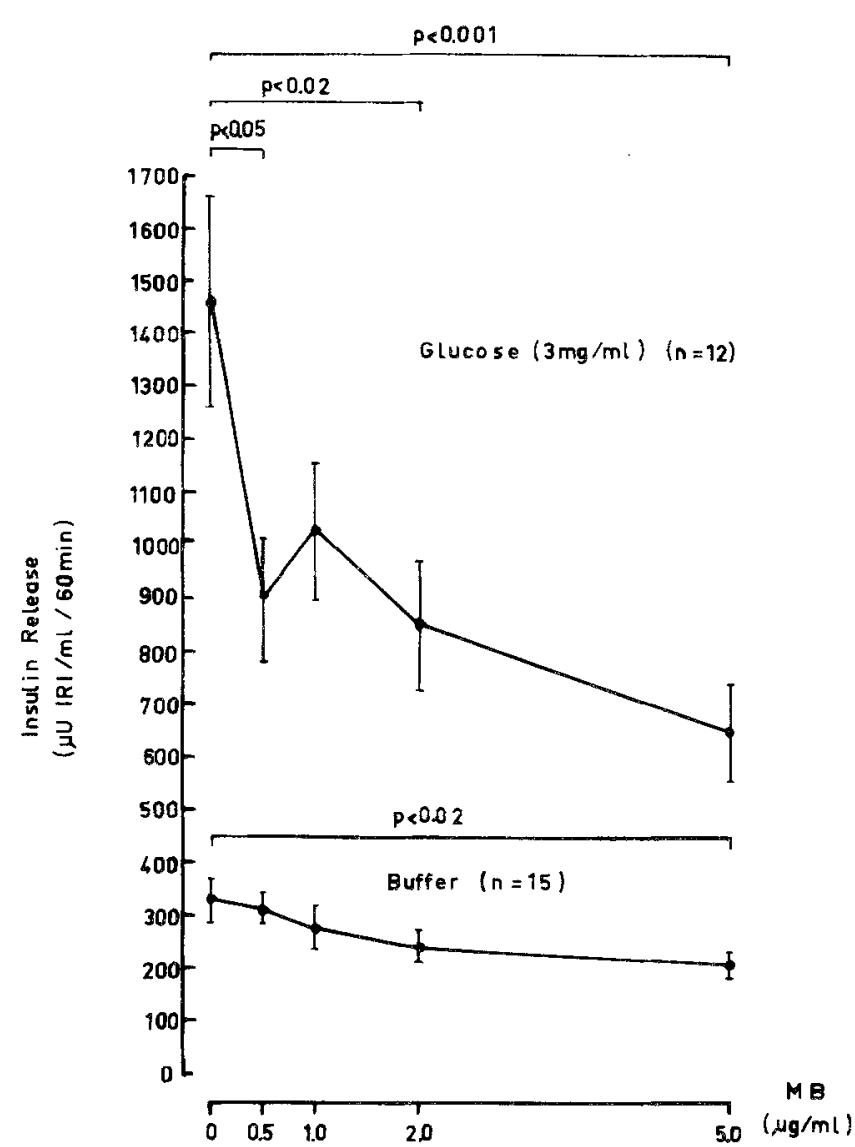

Fig. 2. Effects of Methylene Blue (MB) on glucose-induced insulin release. Ten islets were incubated in $0.7 \mathrm{ml}$ of medium in the presence of $3 \mathrm{mg} / \mathrm{ml}$ of glucose or buffer alone over a period of $60 \mathrm{~min}$. Mean $\pm \mathrm{SEM} ; \mathrm{n}=$ number of experiments. Statisical significance of insulin release in the absence and presence of glucose at each Methylene Blue concentration was at least $p<0.01$

ceivable that this ratio is important for the initiation of glucose-induced insulin secretion. It is also possible that the NADPH/NADP ${ }^{+}$ratio can modulate the response to any secretagogue. This possibility is supported by the fact that the insulin releasing effect of leucine (Akhtar, Ammon, Hoppe, Niklas, unpublished work), tolbutamide or p-chloromercuribenzoate [15] is also inhibited by Methylene Blue though tolbutamide or $\mathrm{p}$-chloromercuribenzoate do not contribute to NADPH production [19].

In conclusion our data suggest that the secretory response of the $\beta$-cell to glucose and a variety of other stimulators of insulin release depends on the NADPH/NADP ${ }^{+}$ratio.

Acknowledgements. These studies were supported by the Deutsche Forschungsgemeinschaft, Bonn-Bad Godesberg, F.R.G. We thank Mrs. X. Hagenloh for skillful technical assistance. 


\section{References}

1. Montague, W., Taylor, K. W.: Pentitols and insulin release by isolated rat islets of Langerhans. Biochem. J. 109, 333-339 (1968)

2. Heinze, E., Steinke, J.: Glucose metabolism of isolated pancreatic islets: Difference between fetal, newborn and adult rats. Endocrinology 88, 1259-1263 (1971)

3. Ammon, H. P. T.: Der Einfluß des Alters auf Glucoseoxidation and Pyridinnukleotide der Langerhansschen Insel. Aktuel. Gerontol. 4, 755-757 (1974)

4. Ammon, H.P.T., Verspohl, E.: Pyridine nucleotides in pancreatic islets during inhibition of insulin release by exogenous insulin. Endocrinology 99, 1469-1476 (1976)

5. Ammon, H.P. T., Steinke, J.: 6-Aminonicotinamide (6-AN) as a diabetogenic agent. In vitro studies in rats. Diabetes 21, 143-148 (1972)

6. Ammon, H. P.T., Patel, T. N., Steinke, J.: The role of the pentose phosphate shunt in glucose-induced insulin release: In vitro studies with 6-aminonicotinamide, Methylene Blue, $\mathrm{NAD}^{+}, \mathrm{NADH}, \mathrm{NADP}^{+}, \mathrm{NADPH}$ and nicotinamide on isolated pancreatic rat islets. Biochim. Biophys. Asta 297, 352-367 (1973)

7. Malaisse, W. J.: Etude de la secretion insulinique in vitro. C. Effets des inhibiteurs du metabolisme glucidique. pp. 53-57. Bruxelles: Arscia 1968

8. Hellman, B., Idahı, L.-A., Lernmark, A., Sehlin, J., Täljedal, I.-B.: Membrane sulphydryl groups and the pancreatic beta cell recognition of insulin secretagogues. 8th Congress Internat. Diabetes Federation. Excerpta Med. Int. Congr. Series 280, 65-78 (1973)

9. Hasart, E., Jacobasch, G., Rapoport, S.: Changes of NAD(P) level in human erythrocytes under varying $\mathrm{pH}$ and under the influence of Methylene Blue. Acta Biol. Med. Germ. 28, 603-613 (1972)

10. Lacy, P. E., Kostianovsky, H.: Methods of isolation of intact islets of Langerhans from the rat pancreas. Diabetes 16, 35-41 (1967)

11. Krebs, H. A., Henseleit, K.: Untersuchungen über die Harnstoffbildung im Tierkörper. Hoppe Seylers Z. Physiol. Chem. 210, 33-66 (1932)
12. Passoneau, J. V., Lowry, O. H.: In: Methoden der enzymatischen Analyse. Bergmeyer, H. U. (Ed.), pp. 2108. Weinheim: Verlag Chemie 1974

13. Matschinsky, F. M.: Recent advances in quantitative histo- and cytochemistry. Adv. Clin. Biochem. 3, 143 (1970)

14. Henning, H.-J., Wartmann R.: Auswertung spärlicher Versuchsdaten im Wahrscheinlichkeitsnetz. Ärtl. Forsch. 12, 60-66 (1958)

15. Ammon, H.P. T., Akhtar, M. S., Niklas, H., Hegner, D.: Inhibition of p-chloromercuribenzoate- and glucose-induced insulin release in vitro by Methylene Blue, diamide and tertButyl hydroperoxide. Mol. Pharmacol. 13, 598-605 (1977)

16. Verspohl, E. J., Händel, M., Ammon, H. P. T.: Pentose-phosphate shunt activity of the rat pancreatic islet: Its dependence on glucose concentration. Endocrinology (in press)

17. Ammon, H.P. T., Grimm, A., Wagner-Teschner, D., Verspohl, E. J., Händel, M.: GSH/GSSG and NADPH/NADP ratios of pancreatic islets depend on glucose concentration. Diabetes 27, 142 (1978) (Abstract)

18. Ammon, H.P.T., Akhtar, M.S., Grimm, A., Niklas, H.: Effect of Methylene Blue and thiol oxidants on pancreatic islet GSH/GSSG ratios and tolbutamide mediated insulin release in vitro. Naunyn Schmiedebergs Arch. Pharmacol. (in press)

19. Ammon, H.P. T.: Effect of tolbutamide on aminophylline-, 3,5-AMP-dibutyrate- or glucagon-induced insulin release from pancreatic islets after impairment of pyridine nucleotide metabolism caused by 6-aminonicotinamide (6-AN). Naunyn Schmiedebergs Arch. Pharmacol. 290, 251-264 (1975)

Received: September 12, 1978

and in revised form: February 5, 1979

Prof. Dr. med. H. P. T. Ammon

Lehrstuhl für Pharmakologie

Pharmazeutisches Institut der Universität

Auf der Morgenstelle 8

D-7400 Tübingen

Federal Republic of Germany 